\title{
Energy Demand Supply Gap and Economic Development nexus in Pakistan
}

\author{
Muhammad Tayyab Ayaz', Tahir Mahmood², Saif-ul-Mujahid Shah
}

${ }^{1}$ M.Phil (Economics) Scholar, School of Economics, Quaid-i-Azam University, Islamabad

${ }^{2}$ Assistant Professor, School of Economics, Quaid-i-Azam University, Islamabad

${ }^{3}$ Ph.D. (Scholar), Faculty of Economics \& Business, University of Malaysia, Sawarak, Malaysia

A B S T R A C T

The demand for energy is rising in Pakistan. This increased in energy demand could be a result of rapid urbanization and economic development. As the economy develops, economic activities, such as industrialization and provision of services rise. These economic activates raise the energy demand. On another hand, Pakistan generating a small amount of energy from its own sources and major part of its energy supply is relying on energy imports. In this study, we analyze the economic development and energy gaps nexus in Pakistan. The data on energy consumption, energy production, energy exports and energy imports is taken from U.S. Energy Information Administration, we use this information to generate aggregate energy supply and energy demand. We also use World development indicators (WDI) in order to get data on financial development, urbanization, and economic growth. We apply the Auto Regressive Distributive Lag (ARDL) bound test. Empirical findings show the marginal effects of financial improvement on energy gaps exists in long as well as in short run. These findings are not sensitive to control additional variables (i.e. urbanization and economic growth). These results show financial development, urbanization, and economic growth increasing the energy demand and supply gaps.

JEL Classification: O4, Q0, Q4

KEYWORDS: Energy Demand, Energy Supply, Economic Development, ARDL.

\section{INTRODUCTION}

The fast innovative developments in the twentieth century have changed energy from ordinary consumer product to an intermediate product (Pierce, 1986). Energy is supposed to be the lifeline of any economy and most essential instrument of financial 
development. There has been a tremendous upsurge in the energy demand because of industrial advancement and populace development in emerging economies. On other side energy supply is far less than energy demand, resultantly energy crisis has emerged.

Energy demand is increasing in Pakistan due to changing demographic trends, rapid urbanization, and economic development. The power burglary and decreases in hydropower have compounded the circumstance. Subsequently, the demand for energy surpasses its supply. For example, the demand for power is 15,000 to $20000 \mathrm{MW}$ for a day in Pakistan. However, we are creating 11,500 MW every day thus there is a deficiency of around 4000 to 9000 MW every day. Expansion in electricity demand and supply gaps can increase the energy price and then high energy price could become the source of energy theft. A study by (Jamil, 2014) shows that electricity theft is one of the main problems and it effects the efficiency of the energy system. The study found that energy price is positively related to electricity theft. A study by (Shahbaz, 2012) found the long run relationship between the consumption of natural gas and economic growth in Pakistan. The study also suggests that natural gas conservation policies may retard economic growth.

Urbanization is one of the causes of high energy demand in Pakistan. The larger cities can play an important role in establishing economic development, and technological advances (Drakakis-Smith, 2000; Rakodi, 1997). These cities are responsible for the generation of most of the economic benefits but equally they consumer some major resources as well as energy and water (Zetter, 2002). Unfortunately, in Pakistan, there is no such comprehensive mechanism till now that can boost the proper utilization of urbanization. The accelerated growth of population, development of infrastructure activities in the city and consequently huge migration to the city has increased the energy demand. For example, the transportation has increased almost 4 folds or even more as compared to last 1 decade (Zafer, 2016).

Energy demand and economic development are increasing in Pakistan. Economic development could be the main reason for rising energy gaps in Pakistan. Here, financial development is used as a proxy for economic development in Pakistan. Empirical findings show a negative relationship between financial development and energy 
demand, these studies argue that financial sector is more energy efficient (Karanfil, 2009; Mielnik, 2002). Therefore, this study is an attempt to investigate the economic development and energy gap nexus in Pakistan.

The data on different sources of energy such as energy consumption, energy production, energy exports and energy imports is taken from U.S. Energy Information Administration. We use this information to generate aggregate energy supply and energy demand. We also use World development indicators (WDI) in order to get data on financial development, urbanization, and economic growth. Financial development is used as an indicator of development. Here, the domestic credit of private sector (\% of GDP) is obtained from the banking sector used as a proxy for financial development. We apply the Auto-Regressive Distributive Lag (ARDL) bound test, it is generally used to analyze the long relationship between the variables, irrespective of their order of integration. Our findings show that the relationship between financial development and energy gaps exists in long as well as in short run. These results show that energy demand and supply gaps are increasing due to economic development and growth in urbanization.

The rest of paper is organized as follow: Section 2 presents the graphical analysis of energy demand and energy supply trends in Pakistan; section 3 outlines the literature review; section 4 explains the data, variables, and methodology; section 5 describes the results and last section is the conclusion.

\section{ENERGY DEMAND AND SUPPLY TRENDS IN PAKISTAN}

Pakistan relies on different sources of energy. In total energy mix, consumption of gas is $43.7 \%$ of total energy, consumption of oil is 29.0 percent, power 15.3 percent, coal 10.4 percent and consumption of LPG is 1.5 percent of total energy mix (Economic Survey of Pakistan, 2014). The demand and supply gap of petroleum products is widening due to higher growth in petroleum demand as compared to petroleum supply (Figure, 2.1). This gap is fluctuating over the time 1980 to 2014, which shows volatility and uncertainty. Both the demand and supply growth is negative from 2002 to 2004 and from 2010 to 2012. In this period revolutionary change occurred in transport sector because most of the consumer converted their transport from Petrol to CNG. Therefore, 
decrease in demand and supply in petroleum in 2002 to 2004 is due to this transformation. Pakistan still heavily rely on petroleum in order to fulfill its energy demand. Petroleum demand of Pakistan is not fulfilled by the domestic resources. Pakistan import oil from the Middle East especially from Saudi Arabia. Approximately 90\% of Pakistan petroleum products need is fulfilled by the imports. The current decline in petroleum prices will increase both demand and supply of petrol and both growth rates are positive(!!! INVALID CITATION !!! ; Pakistan, 2014-15) (Economic Survey of Pakistan, 2015).

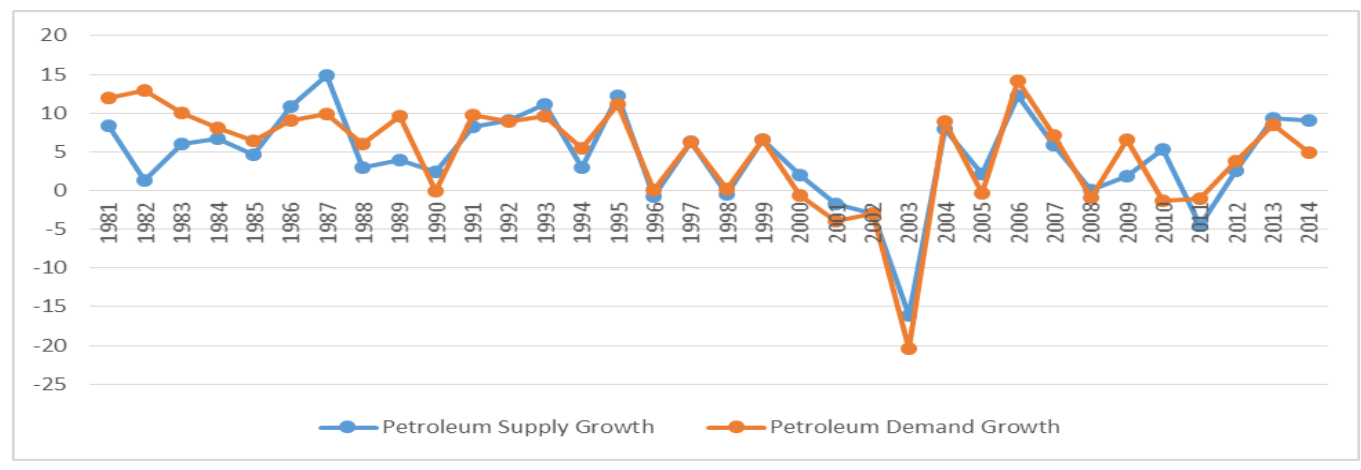

Figure 2.1: Petroleum Products Demand and Supply Growth Rate

The growth rate of electricity supply and demand is shown in Figure 2.2. The growth in electricity demand is higher than the growth in electricity supply. The electricity crisis across the country worsen the life of the peoples. The electricity shortfall in big cities is around 8 to 10 hours in the summer season and in small cities and villages this shortfall is around 12 to 14 hours. This shortfall is due to the incompetence of the government and mismanagement in the energy sector (Valasai, 2017). The electricity demand and supply gap are widening more and more due to increase in the demand for electricity and less generation of electricity.

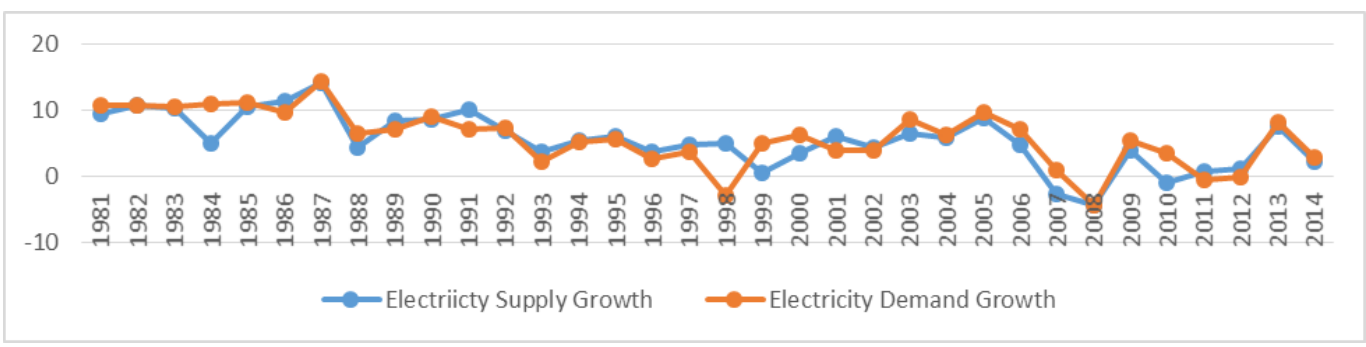




\section{Figure 2.2: Electricity Demand and Supply Growth Rate}

The coal reserves of Pakistan is approximately 185 billion tonnes, out of which 175 billion tones are from Thar coal fields. Figure 2.3 shows the dynamics of coal demand and supply in Pakistan. The growth in coal demand was approximately equal to its supply during the period 1980-2014.

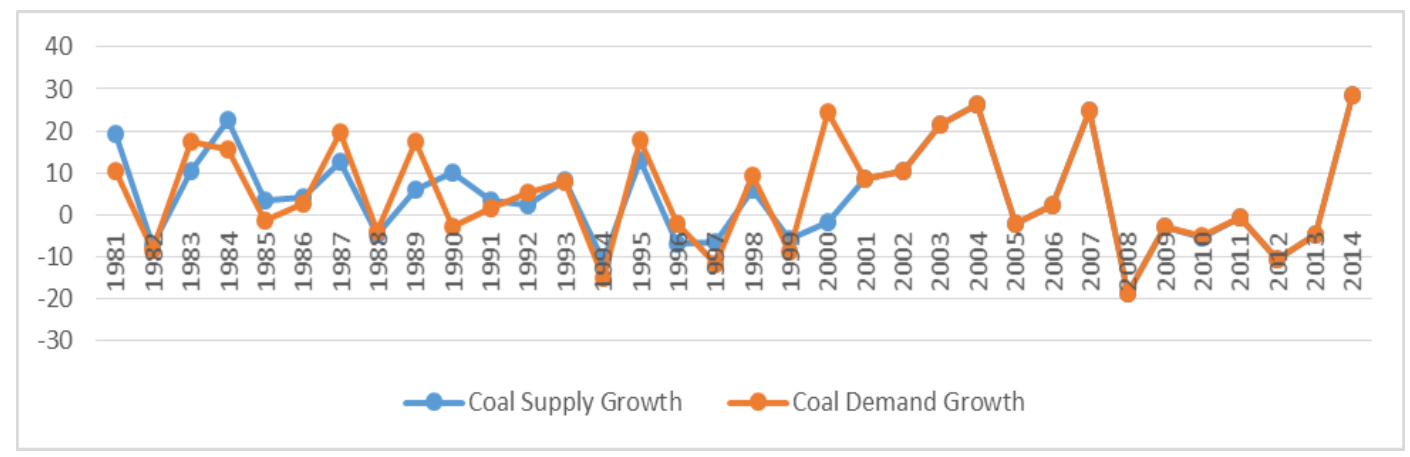

Figure 2.3: Coal Demand and Supply Growth Rate

The usage of natural gas is rising in Pakistan since 2003. Natural gas production is around 4048.76 million cubic feet per day. It increased by 1.56 percent as compared to last year. Most of the natural gas usage is in the industry to produce consumer goods, and generate electricity. In the form of CNG, Pakistan is the biggest user of CNG in the world and it is utilized in the transport sector of the country. In the consumption of energy, the share of natural gas is around 44\%. Many of the private and public transport vehicles converted their cars from petrol to CNG during 2005 to 2010 because of high petrol prices. Figure 2.4 shows the trend of natural gas.

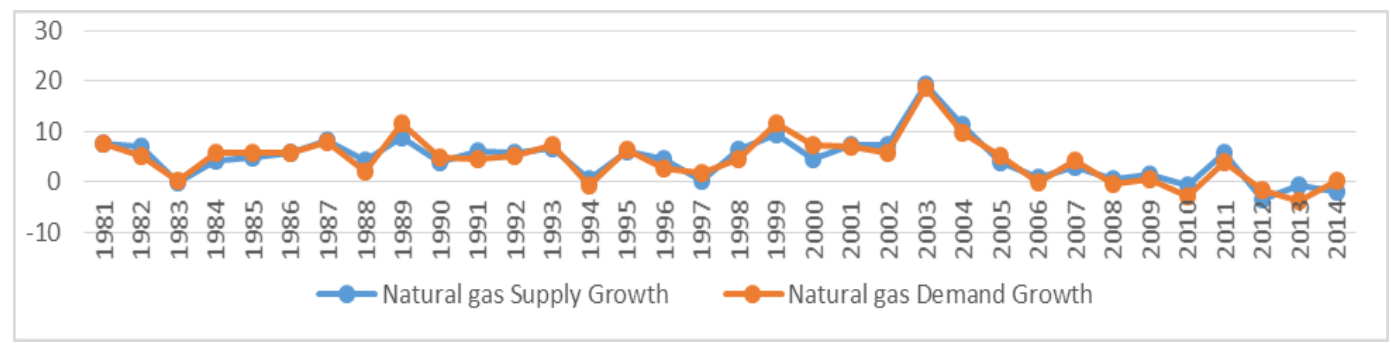

Figure 2.4: Natural Gas Demand and Supply Growth Rate

\section{LITERATURE REVIEW}

During last five to six years a lot of research has been conducted on energy demand-supply gap (Cherp, 2014). Many of these research concerned the four A's of 
energy security “Availability, Accessibility, Affordability, and Acceptability”. A study by Asia Pacific energy research centre utilized this four A's structure to set up an information regarding energy security in Asia, however, this report does not legitimize the usage of four A's, as of past research and experimental observations (APERC, 2007). To investigate the china energy security condition this 4 A's structure has been used. It concludes that China energy sector was at its peak from 1981 to 1985 and it gets worse during 2006 to 2010 (Yao, 2014).

(Kraft, 1978) emphasized the significance of energy in economic progress. So as to find the direction of connection between economic progress and demand for energy. A study by (Chontanawat, 2006) used three different methodologies on three different groups. In the first group, they used the (Granger, 1969) and (Sims, 1972) methodologies and it was based on the USA and some other established economies. In a second group, they applied the co-integration and ECM on different industrialized and unindustrialized countries and (Hsiao, 1981) technique is used the third group in Asian Developing Countries. The study concludes that economic development and energy has a strong relationship. The demand for energy is rising throughout the human history due to population growth, economic development and heavy flux of urbanization.

According to the United Nations, the world population reaching 9.1 billion in 2050. The Asia and Africa are the main source of rising population, these regions are energy deficient and on the verge of energy insecurity. Pakistan's energy sector is not well organized and it is thought to be ineffectively managed. Regardless of resilient economic development and rising demand for energy in past years, no genuine endeavors have been made to increase the production of electricity. Furthermore, growing energy demand, distribution, and transmission losses due to the outmoded substructure, power theft, and regular decreases in the accessibility of hydropower have aggravated the conditions. Energy is considered as the very important determinant in the economic development of any country. So, its unavailability can impede the economic growth. In order to improve the energy sector. It is very important for energy policymakers to shift their focus to alternative energy sources (Siddiqui, 2004).

During the twentieth century, a rapid urbanization activity is forecasted in world 
demographic trends. This is estimated that total world energy consumption of marketed energy is expected to expand by $57 \%$ over the $2002-25$ time periods. Presently, more than $33 \%$ population of Pakistan is living in the urban areas. It is a fact that the growth in urban areas has not taken place as it was expected. Population Census in 2011 indicates that a number of communities are now the part of the urban population which were previously the part of rural areas. This census also indicated that population of Pakistan was 179.4 million having a rate of growth $2.7 \%$ per year from 1981-98. It is evident that the growth rate was higher than as projected, and the rate remained $3.5 \%$ per year for the period. In 2011 urban population was counted as 59.7 million. Therefore, it is safely concluded that urban population in Pakistan is about $33 \%$ of its total population. It is also a fact that for the period of 1951-2011, the whole population of the country has increased to about 4 times but urban growth is more than that of 7 times (Zafer, 2016).

South Asian economies are based on industrial and services sector. Shares of industry and services in GDP are increasing in these countries. The energy demand of these economies is also increasing. The increase in power utilization affects the GDP in the developing countries like Pakistan and Sirilanka. The association between different sources of energy and economic development exist in South Asian economies (Zahid, 2008). Another study by (Asafu-Adjaye, 2000) finds that the energy demand affects economic growth in the short run. On the contrary, the energy gap between the South Asian countries widening due to rising cost of energy supply. The cause of this escalation in cost is a lack of connections and trade among these countries. South Asian countries do not coordinate with each other and there are no gas pipelines that overpasses the state boundaries and access to the substantial energy resources in the neighboring nations are denied. On the off chance that the nations participate with each other and start trading the different energy sources than South Asia turn into the world biggest unified energy marketplace (Singh, 2013). Therefore, Lack of regional trade in the energy sector is also affecting the energy demand and supply gaps. The energy demand and supply imbalances in South Asia rising due to the low volume of trade between the countries of the region.

\section{DATA, VARIABLES, AND METHODOLOGY}

Data on energy consumption, energy production, energy imports and energy 
exports is taken from Energy Information Administration. Information on these variables is available only from 1980 to 2014 . We use this data to generate aggregate energy supply and energy demand. Energy demand and energy supply are measured in BTU.

We use financial development as an indicator of development. Here, we use the domestic credit of private sector (\% of GDP) which is obtained from the banking sector as a proxy for financial development. Data on other development indicators such as GDP per capita and urbanization is also taken from World Development Indicator (WDI).

We proposed following empirical models to analyze the relationship between energy demand and supply gaps, financial development, urbanization and economic growth. For empirical analysis, we use following model specification, this specification is also adopted by (Shahbaz, 2012). The log linear form of the model is as follow:

$E D S G=f(G D P, F D, U R B, P O P)$ Eq. 4.1

$\ln E D S G_{t}=\alpha_{1}+\alpha_{2} \ln G D P_{t}+\alpha_{3} \ln F D_{t}+\alpha_{4} \ln U R B_{t}+\varepsilon_{t}$ .Eq. 4.2

Here, $\ln E D S G_{t}$ is the natural log of energy demand and supply gap at time period $\mathrm{t}, \ln F D_{t}$ is the natural $\log$ domestic credit of private sector, which is used as a proxy for financial development. $\ln u r b_{t}$ is the natural log of urban population which is used as a proxy for urbanization and $\ln g d p c_{t}$ is the natural $\log$ of GDP per capita which is used as a proxy to measure the standard of living or economic growth. Here, we apply the Auto Regressive Distributive Lag (ARDL) bound test, it is generally used to analyze the long relationship between the variables, irrespective of their order of integration (Pesaran, 2001).

$$
\begin{aligned}
& \Delta \ln E D S G_{t}=\alpha_{\circ}+\sum_{j=1}^{p} \alpha_{i} \Delta \ln E D S G_{t-j}+\sum_{j=1}^{p} \beta_{i} \Delta \ln F D_{t-j}+ \\
& \sum_{j=1}^{p} \gamma_{i} \Delta \ln G D P c_{t-j}+\sum_{j=1}^{p} \delta_{i} \Delta \ln U R B_{t-j}+\varphi_{1} \ln E D S G_{t-1}+\varphi_{2} \ln F D_{t-1}+ \\
& \varphi_{3} \ln G D P c_{t-1}+\varphi_{4} \ln U R B_{t-1}+u_{t}
\end{aligned}
$$

Where is the growth rate of energy demand and supply gaps at time period t, 
$\Delta \ln F D_{t}$ is the growth rate of financial development, $\Delta \ln U R B_{t}$ is the growth rate of urbanization and $\Delta \ln G D P c_{t}$ is the growth rate of GDP per capita. In above equation, on the right-hand side the expression from $\varphi_{1}$ to $\varphi_{4}$ portray the long run relationship. The hypothesis of no co-integration in Eq. (4.3) is the alternative hypothesis $H_{0}=\varphi_{1} \neq \varphi_{2} \neq \varphi_{3} \neq \varphi_{4} \neq 0$. If cointegration exists, we estimate conditional ARDL long-run model.

$\ln E D S G_{t}=\alpha_{1}+\alpha_{2} \ln G D P_{t}+\alpha_{3} \ln F D_{t}+\alpha_{4} \ln U R B_{t}+\varepsilon_{t}$ .Eq.4.4

In the next stage, we obtain short-run dynamic parameters by using following error correction model (ECM) which associated with the long-run estimates:

$$
\begin{aligned}
\Delta \ln E D S G_{t}= & \alpha_{o}+\sum_{j=1}^{p} \alpha_{i} \Delta \ln E D S G_{t-j}+\sum_{j=1}^{p} \beta_{i} \Delta \ln F D_{t-j}+\sum_{j=1}^{p} \gamma_{i} \Delta \ln G D P c_{t-j} \\
& +\sum_{j=1}^{p} \delta_{i} \Delta \ln U R B_{t-j}+\theta \varepsilon_{t-1}^{\infty}+u_{t}
\end{aligned}
$$

Eq.4.5

The coefficients with the summation signs show the short-run dynamics. Whereas, ${ }^{\alpha} \circ$ is the drift constants in the equation. While reveals Guassian white noise. The long run, as well as short run coefficient, will be estimated through this model. Schwarz Bayesian Criteria (SBC) and Akaike Information Criteria (AIC) are taken into account for the relevant model selection.

\section{FINDINGS AND DISCUSSION}

It is quite essential to check the stationary of variables before the estimation of ARDL model. For this purpose, we use augmented dickey fuller (ADF) and PhillipsPerron (PP) tests. Table 5.1 shows that all the series are integrated of order one I (1). 


\begin{tabular}{|c|c|c|c|c|}
\hline Table 5.1: Unit Root Test & \multicolumn{2}{c|}{ ADF-test } & \multicolumn{2}{c|}{ PP-test } \\
\cline { 2 - 5 } & $p$-value & $t$-value & $p$-value & $t$-value \\
\hline $\ln E D S G_{t}$ & 0.890 & -0.44 & 0.842 & -0.66 \\
\hline $\ln F D_{t}$ & 0.785 & -0.86 & 0.582 & -1.37 \\
\hline $\ln G D P_{t}$ & 0.732 & -1.02 & 0.570 & -1.40 \\
\hline $\ln U R B_{t}$ & 0.971 & 0.24 & 0.941 & 0.35 \\
\hline$\Delta \ln E D S G_{t}$ & $0.000^{*}$ & -4.89 & $0.000^{*}$ & -4.89 \\
\hline$\Delta \ln F D_{t}$ & $0.002^{*}$ & -4.19 & $0.002^{*}$ & $-4-19$ \\
\hline$\Delta \ln G D P_{t}$ & $0.009^{*}$ & -3.69 & $0.010^{*}$ & -3.65 \\
\hline$\Delta \ln U R B_{t}$ & 0.162 & -2.35 & $0.061^{* * *}$ & -1.85 \\
\hline
\end{tabular}

Note: *, ** and *** are $1 \%, 5 \%$ and $10 \%$ level of significances

The ARDL shows the long run relationship between variables. The bounds tests shown in Table 5.2, reject the null hypothesis of no long-run relationship when energy gap is treated as a dependent variable and financial development (FD), urbanization (UBR) GDP per capita (GDP) are treated as independent variables. Therefore, there is a long run equilibrium relationship exists between these variables. The long-run elasticity is also shown in Table 5.3.

\begin{tabular}{|l|l|c|c|c|c|}
\hline \multicolumn{1}{|c}{ Table 5.2: Cointegration Test (bounds test). } \\
\hline $\begin{array}{c}\text { Lag and } \\
\text { Length }\end{array}$ & $\begin{array}{c}\text { F- } \\
\text { statistic }\end{array}$ & $\begin{array}{c}\text { Lower- } \\
\text { upper } \\
\text { bound at } \\
1 \%\end{array}$ & $\begin{array}{c}\text { Lower- } \\
\text { upper bound } \\
\text { at 5\% }\end{array}$ & $\begin{array}{c}\text { Lower- } \\
\text { upper } \\
\text { bound at } \\
5 \%\end{array}$ \\
\hline F(EDSG/FD,URB,GDPc)** & 02 & 6.50 & $7.86-8.90$ & $5.20-6.13$ & $4.15-5.01$ \\
\hline F(FD/EDSG,URB,GDPc) & 02 & 1.45 & $7.86-8.82$ & $5.7-6.11$ & $4.31-5.44$ \\
\hline F(URB/EDSG,FD,GDPc) & 02 & 2.08 & $7.70-8.72$ & $5.36-6.19$ & $4.11-5.14$ \\
\hline F(GDPc/EDSG,FD,URB) & 02 & 3.20 & $7.70-8.02$ & $5.20-6.23$ & $4.22-5.34$ \\
\hline
\end{tabular}

Note: ** denotes the $5 \%$ level of significances

Long run or cointegrating relationship exists among the energy gap, financial development, urbanization and economic growth. The results in Table 5.3 show the marginal impacts of financial development, urbanization and economic growth on energy gaps in the long run. These results show the coefficient of financial development is 0.016 which is positive and significant. This means that an increase of $1 \%$ in domestic credit of private sector will increase energy demand and supply gap by $0.016 \%$ for Pakistan in 
long run. Similarly, urbanization is also positively related to an energy gap. After examining the long run relationship, now analyze the impact of financial development, urbanization and economic growth on energy gaps in the short run. The short run results are presented in table 5.4. The growth rate of GDP per capita is positive, which specifies that increase in per capita income will increase the purchasing power and people will raise the demand for electronic equipment and automobiles product. Consequently, it increases the energy demand and energy supply gaps. The coefficient of urbanization is positive and significant, which indicates that $1 \%$ increase in urban population will widen the energy gap

\begin{tabular}{|lc|}
\hline \multicolumn{2}{|l|}{ Table 5.3: Results of Long Run Relationship } \\
\hline${\text { ln } E D S G_{t}}_{t}=\alpha_{1}+\alpha_{2} \ln G D P_{t}+\alpha_{2} \ln F D_{t}+\alpha_{4} \ln U R B_{t}+\varepsilon_{x_{t}}$ \\
Dependent variable: $\ln E D S G_{t}$ \\
\hline Variable & Coefficient \\
C & $1.02^{* * *}$ \\
$\ln F D_{t}$ & $0.016^{* * *}$ \\
$\ln U R B_{t}$ & $0.06^{* * *}$ \\
$\ln G D P c_{t}$ & $0.04^{* * *}$ \\
\hline No of Observations & 32 \\
$R^{2}$ & 0.45 \\
\hline
\end{tabular}

\begin{tabular}{|l|c|c|c|}
\hline \multicolumn{4}{|c|}{ Table 5.4: Output for Short Run Linear Regression Model. } \\
\hline & Equation 1 & Equation 2 & Equation 3 \\
\hline \multirow{2}{*}{ Constant } & 1.178 & 3.304 & 0.386 \\
& {$[1.08](0.33)$} & {$[5.74](0.00)$} & {$[1.76](0.09)$} \\
\hline \multirow{2}{*}{$\Delta \ln F D_{t}$} & 0.026 & 0.032 & 0.029 \\
& {$[3.07](0.03)$} & {$[4.55](0.001)$} & {$[-2.16](0.03)$} \\
\hline \multirow{2}{*}{$\ln G D P_{t}$} & 0.063 & 0.09 & \\
\hline \multirow{2}{*}{$\Delta \ln U R B_{t}$} & {$[2.34](0.07)$} & {$[3.59](0.005)$} & \\
\hline R-squared & 0.051 & & 0.043 \\
\hline D.W statistic & {$[1.54](0.18)$} & - & {$[1.85](0.07)$} \\
\hline F-Statistic (p-value) & 0.72 & 0.64 & 0.24 \\
\hline No of Observations & 1.74 & 2.05 & 1.96 \\
\hline
\end{tabular}

Note: $p$-values are in parenthesis and $t$-values are in square brackets 
The results show that the coefficient of financial development is positive and statistically significant. This suggests that $1 \%$ increase in domestic credit to the private sector will increase the energy gap (energy crisis) by around $0.02 \%$. This implies that economic development widening energy gaps in Pakistan through increasing the energy demand. These results are consistent with existing literature (Aqeel, 2001; Ghali, 2004; Morimoto, 2004). Financial development is one of the main determinants of growth in the industrial sector, it generates demand for new infrastructure; and therefore, it is positively related to energy demand (Islam, 2013). Another study by (Sadorsky, 2010) also found a positive relationship between financial development and energy demand. Some empirical findings show a negative relationship between financial development and energy demand, these studies argue that financial sector is more energy efficient (Karanfil, 2009; Mielnik, 2002). The financial sector of Pakistan growing and it is an initial stage of development. Therefore, it is more energy intensive as compared to financial sectors in developed economies. Results in table 5.4 also show that our findings are not sensitive to control additional variables (i.e. urbanization and economic growth).

\section{CONCLUSION}

The aim of this study is to investigate the energy demand-supply gap and economic development nexus in Pakistan from 1980-2014. We use financial development as an indicator of development. Urbanization and per capita income are also used as indicators of development. The data on energy consumption, energy production, energy exports and energy imports is taken from U.S. Energy Information Administration, we used this information to generate the series of energy demand and energy supply. We apply the Auto Regressive Distributive Lag (ARDL) bound test, it is generally used to analyze the long relationship between the series, irrespective of their order of integration. Our findings show that the relationship between financial development and energy gaps exists in long as well as in short run. These results show that energy demand and supply gaps are increasing both in short run as well as in long run due to growth in financial development growth in urbanization and due to economic growth.

Therefore, In order to reduce energy demand and supply gaps, the government should ensure planned urbanization and economic development. Policymakers should 
shift their focus to renewable energy sources. The government should reduce the energy demand through energy conservation policy, it will be more cost effective than increasing the energy supply.

The role of CPEC is very vital for the future energy security of Pakistan. Because out of $\$ 57$ billion under CPEC framework, the share of the energy sector is around $\$ 35$ billion. Government is making all efforts to attain the long-term vision of the energy sector to overcome all the challenges. Around 10,400 MW of electricity will be added to the grid under the CPEC project during the year 2018. The projects include coal, hydro and wind. It will likewise ominously change the energy mix, substituting expensive oil and causing the reduction of the average cost of generation (Economic Survey of Pakistan 2015-16). It is believed that with earnest endeavors of the government, it will be conceivable to build a power generation capacity that can meet Pakistan's energy demand in a viable way.

The study does not distinguish between energy demand and supply gaps at sectoral level (i.e. energy gaps in agriculture, industrial and services sector), it is one of the main limitations of this study. A disaggregate analysis on this line would be much helpful for policymakers, especially to revise the policy measures in case the result differ between the two categories of energy gaps and their relationship with development at sectoral level.

\section{REFERENCES}

\section{. (!!! INVALID CITATION !!! ).}

APERC, A. P. E. R. C. (2007). A Quest for Energy Security in the 21st Century: Resources and Constraints. Retrieved from Tokyo:

Aqeel, A. B., Mohammad Sabihuddin. (2001). The Relationship between Energy Consumption and Economic Growth in Pakistan. Asia-Pacific Development Journal, 8(2), 101-110.

Asafu-Adjaye, J. (2000). The relationship between energy consumption, energy prices and economic growth: Time series evidence from Asian developing countries. Energy Economics, 22(6), 615-625.

Cherp, A. J., Jessica. (2014). The concept of Energy Security: Beyond the four As. Energy Policy, $75,415-421$.

Chontanawat, J. H., Lester C; Pierse, Richard. (2006). Causality between Energy Consumption and GDP: Evidence from 30 OECD and 78 Non-OECD Countries. Surrey Energy Economics Centre (SEEC).

Drakakis-Smith, D. (2000). Routledge Introductions to Development series: Third World cities: Routledge.

Ghali, K. H. E.-S., M.I.T. (2004). Energy use and output growth in Canada: a multivariate cointegration analysis. Energy Economics, 26, 225-238. 
Granger, C. W. J. (1969). Investigating Causal Relations by Econometric Models and CrossSpectral Methods. Econometrica, 36, 424-438.

Hsiao, C. (1981). Autoregressive Modelling and Money-Income Causality Direction. Journal of Monetary Economics, 7, 85-106.

Islam, F. S., Muhammad; Ahmed, Ashraf U.; Alam, Md. Mahmudul. (2013). Financial development and energy consumption nexus in Malaysia: A multivariate time series analysis. Economic Modeling, 30, 435-441.

Jamil, F. A., E. (2014). An empirical study of electricity theft from electricity distribution companies in Pakistan. Pakistan Development Review, 53(3), 239-251.

Karanfil, F. (2009). How many times again will we examine the energy-income nexus using a limited range of traditional econometric tools? . Energy Policy, 37, 1191-1195.

Kraft, J. K., A. (1978). On the Relationship between Energy and GNP. Journal of Energy and Development, 3, 401-413.

Mielnik, J. G. (2002). Foreign direct investment and decoupling between energy and gross domestic product in developing countries. Energy Policy, 30, 87-89.

Morimoto, R. H., Chris. (2004). The impact of electricity supply on economic growth in Sri Lanka. Energy Economics, 26, 77-85.

Pakistan, G. o. (2014-15). Economic Survey of Pakistan. Pakistan: Ministry of Finance.

Pesaran, H., Shin, Y., \& Smith, R. (2001). Bounds Testing Approaches to the Analysis of Level Relationship. Journal of Applied Econometrics, 16(3), 289-326.

Pierce, W. S. (1986). Economics of Energy Industries. Retrieved from Belmont:

Rakodi, C. (1997). Global force, Urban change and Urban management in Africa, The Urban Challenge in Africa: Growth and Management of its large cities. United Nation University Press, 17-73.

Sadorsky, P. (2010). The impact of financial development on energy consumption in emerging economies. Energy Policy, 38, 2528-2535.

Shahbaz, M. L., Hooi Hooi. (2012). Does financial development increase energy consumption? The role of industrialization and urbanization in Tunisia. Energy Policy, 40, 473-479.

Siddiqui, R. (2004). Energy and Economic Growth in Pakistan. The Pakistan Development Review, 43(2), 175-200.

Sims, C. A. (1972). Money, Income, and Causality. The American Economic Review, 62, 540-552.

Singh, B. K. (2013). South Asia energy security: Challenges and opportunities. Energy Policy, 63, 458-468.

Valasai, G. D. U., Muhammad Aslam; Memon, HafeezUr Rahman; Samoo, Saleem Raza; Mirjat, Nayyar Hussain; Harijan, Khanji. (2017). Overcoming electricity crisis in Pakistan: A review of sustainable electricity options. Renewable and Sustainable Energy Reviews, 72, 734-745.

Yao, L. C., Youngho. (2014). Energy security in China: A quantitative analysis. Energy Policy, 67, 595-604.

Zafer, K. S. (2016). Problem of Urbanization in Peshawar. (MPhil Dissertation), National Defense University Islamabad,

Zahid, K. (2008). Energy-GDP Relationship: A Causal Analysis for the Five Countries of South Asia. Applied Econometrics and International Development, 8(1), 167-180.

Zetter, R. (2002). Market enablement or sustainable development: the conflicting paradigms of urbanization, Planning in the cities: sustainability and growth the developing world. Retrieved from London: 